41. Murphy, B. E. P.: Some studies of the protein-binding of steroids and their application to the routine micro and ultramicro measurement of various steroids in body fluids by competitive protein-binding radioassay. J. Clin. Endocrinol. Metab., 27: 973 (1967).

42. Nelson, N.: A photometric adaptation of the Somogyi method for the determination of glucose. J. Biol. Chem., 153: 375 (1944).

43. Outschoorn, A. S.: The hormones of the adrenal medulla and their release. Brit. J. Pharmacol., 7: 605 (1952)

44. Perkoff, G. T., and Tyler, F. H.: Paradoxical hyperglycemia in diabetic patients treated with insulin. Metabolism, 3: 110 (1954)

45. Roth, J., Glick, S. M., Yalow, R. S., and Berson, S. A.: Hypoglycemia: A poten stimulus to secretion of growth hormone. Science, 140: 987 (1963)

46. Sabeh, G., Mendelsohn, L. V., Corredor, D. G., Sunder, J. H., Friedman, L. M., Morgan, C. R., and Danowski, T. S.: Growth hormone in insulin-treated diabetes mellitus. Metabolism, 18: 748 (1969).

47. Schalch, D. S., and Parker, M. L.: A sensitive double antibody immunoassay for human growth hormone in plasma. Nature, 203: 1141 (1964).

48. Schnure, J. J., Raskin, P., and Lipman, R. L.: Growth hormone secretion during sleep: impairment in glucose tolerance and nonsuppressibility by hyperglycemia. J. Clin. Endocrinol. Metab., 33: 234 (1971).

49. Service, F. J., Molnar, G. D., Rosevear, J. W., Ackerman, E., Gatewood, L. C. and Taylor, W. F.: Mean amplitude of glycemic excursions, a measure of diabetic instability. Diabetes, 19: 644 (1970).

50. Somogyi, M.: Exacerbation of diabetes by excess insulin action. Amer. J. Med. 26: 169 (1959).

51. Somogyi, M.: Diabetogenic effect of hyperinsulinism. Amer. J. Med., 26: 192 (1959)

52. Somogyi, M., and Kirstein, M. B.: Insulin as a cause of extreme hyperglycemia and instability. Week. Bull. St. Louis Med. Soc., 32: 498 (1938),

53. Sperling, M. A.. Bacon, G., Kenny, F. M., and Drash, A. L.: Cortisol secretion in acidotic and nonacidotic diabetes mellitus. Amer. J. Dis. Child., I24: 690
(1972).

54. Tietze, H. U., Zurbrügg, R. P Zuppinger, K. A., Joss, E. E., and Käser, H : Occurrence of impaired cortisol regulation in children with hypoglycemia associated with adrenal medullary hyporesponsiveness. J. Clin. Endocrinol. Metab., 34: 948 (1972)

55. Unger, R. H.: High growth-hormone levels in diabetic ketoacidosis: A possible cause of insulin resistance. J. Amer. Med. Ass., 191: 945 (1965).

56. Voorhess, M. L.: Urinary catecholamine excretion by healthy children. I. Daily excretion of dopamine, norepinephrine, epinephrine and 3-methoxy-4hydroxymandelic acid. Pediatrics, 39: 252 (1967).

57. Wallace, J. M., and Harlan, W. R.: Significance of epinephrine in insulin hypoglycemia in man. Amer. J. Med., 38: 531 (1965).

58. Yalow, R S. Goldsmith, S. J., and Berson, S. A. Influence of physiologic fluctuations in plasma growth hormone on glucose tolerance. Diabetes, $18: 402$ (1969).

59. Bio-Science Laboratories, Van Nuys, Calif

60. This work was performed in the Clinical Research Center of the Children's Hospital of Buffalo, supported by a grant (RR 628) from the General Clinical Research Centers Program of the Division of Research Resources, National Institutes of Health. It was also supported by the Department of Health, Education and Welfare, Maternal and Child Health Service (Project 417). Parts of this material were presented in the Endocrinology Section at the joint meeting of the American Pediatric Society and the Society for Pediatric Research in Atlantic City, April 30, 1971; in the Round Table on Diabetes Mellitus at the XIIIth International Congress of Pediatrics, Vienna, September 1971: and in a lecture to the pediatric staff of the Georgetown University Hospital, Washington, D.C. October 29, 1971 in the course of a Visiting Professorship sponsored by the Journal of Pediatrics Educational Foundation.

61. Requests for reprints should be addressed to: E. Bruck, M. D., Children's Hospital of Buffalo, 219 Bryant St., Buffalo, N. Y. 14222 (USA).

62. Accepted for publication March 10, 1975.
Agammaglobulinemia lymphocytes $\mathrm{B}$ cell disorders immunoglobulin

\title{
The Use of Transfer Factor in a Patient with Agammaglobulinemia
}

\author{
NIEVES M. ZALDIVAR, (39) PHOTINI S. PAPAGEORGIOU, SARAH KAFEE, AND \\ PHILIP R. GLADE \\ Department of Pediatrics, Division of Infectious Diseases, Mount Sinai School of Medicine of the City \\ University of New York, New York, New York, USA
}

Extract

We have studied a 9-year-old boy with agammaglobulinemia treated for the past 6 years with exogenous $\gamma$-globulin who was noted to have an immunoglobulin (Ig) $M$ level of $35 \mathrm{mg} / 100 \mathrm{ml}$ and circulating $B$ cells as determined by immunofluorescence. Of the circulating lymphocytes, $41 \%$ had $\alpha$-immunoglobulin heavy chains, 3\% $\gamma$ chains, and 3\% $\mu$ chains. Synthesis of $\gamma$ heavy chain classes showing wide heterogeneity and $\alpha$ and $\mu$ chains of restricted mobility was demonstrated by radioimmunoelectrophoresis. Because of the patient's poor clinical response to exogenous $\gamma$-globulin administration and the paradoxic presence of circulating $B$ cells, with the capacity to synthesize immunoglobulins in vitro, we elected to begin a course of therapy with transfer factor. After the initial four doses of transfer factor $\left(2 \times 10^{8}\right.$ lymphocytes/dose $)$ his serum IgG rose from 50 to $130 \mathrm{mg} / 100 \mathrm{ml}$, the same level which he had previously attained during continuous exogenous $\gamma$-globulin therapy. His serum IgG has remained at this level for the past 12 months with trimonthly booster doses of transfer factor. The patient has not required any additional $\gamma$-globulin therapy and he has remained clinically asymptomatic.

\section{Speculation}

Our studies in a patient with agammaglobulinemia have shown that transfer factor therapy may affect immunoglobulin synthesis. The concurrent discontinuation of exogenous $\gamma$-globulin administration makes it difficult to attribute the changes to only one or another aspect of therapy. We await further reports of the effects of transfer factor in the therapy of patients with B cell disorders.

Congenital agammaglobulinemia has been considered a stem cell deficiency involving thymic-independent B lymphocytes with sparing of thymic-dependent $T$ lymphocytes. The paradoxic finding of $\mathrm{B}$ lymphocytes with surface immunoglobulins and receptors for complement in the peripheral circulation of some patients with agammaglobulinemia $(16,19)$, however, argues against a stem cell origin for this disorder. Extensive investigations in the mouse confirm that $\mathrm{T}$ lymphocytes are instrumental in the facilitation and suppression of immunoglobulin and antibody production by $B$ lymphocytes (13). Recent studies in man have further demonstrated a variable $T$ lymphocyte deficiency in some patients with the clinical and laboratory manifestations of congenital agammaglobulinemia (21). These findings suggest that the B cell dysfunc- 
tion that occurs in some patients with agammaglobulinemia may result from faulty $\mathrm{T}$-B cell interaction.

Transfer factor, a dialyzable extract of peripheral blood leukocytes, has been shown to transfer to the recipient the specific cell-mediated immune responses of the donor (14). Transfer factor administration in the Wiskott-Aldrich syndrome has resulted in a general improvement in the condition of these patients $(23,24)$, suggesting that transfer factor may nonspecifically augment immune responses as well. Although the effects of transfer factor on T-B cell interaction have not been defined, such an effect could explain these "nonspecific" findings. Our experience with the use of transfer factor to alter the clinical course of a patient with agammaglobulinemia suggests that transfer factor may have the potential to influence $\mathrm{T}-\mathrm{B}$ cell interaction.

\section{CASE HISTORY}

$J F$, a 9-year-old male foster child, the 9-1b, 3-oz product of a reportedly normal pregnancy and delivery, has had a long standing history of frequent infections with hospitalizations beginning in his perinatal period. He spent the first 6 months of his life in an isolation ward because of recurrent sepsis and pneumonia. His repeated infections have included otitis media (which led to bilateral deafness by 3 years of age), pneumonia, impetigo, and bacterial meningitis. At the age of 3 years the diagnosis of agammaglobulinemia was made and he was subsequently treated with biweekly doses of $0.6 \mathrm{ml} / \mathrm{kg}$ commercial $\gamma$-globulin until he was 8 years old. In spite of this therapy the frequency and severity of his infections did not abate and he was referred to the Department of Pediatrics, Division of Infectious Diseases of the Mount Sinai School of Medicine for further evaluation and treatment.

He was initially seen on January 24, 1973 and was found to be well developed with a height of 52 inches (50th percentile) and weight of $70 \mathrm{lb}$ (50th percentile), with abnormally shaped ears, a barrel chest, and bilateral rales. Hyperkinetic behavior and a speech defect were noted. These had led previously to numerous neurologic evaluations, all of which were considered normal. His peculiar behavior has since been attributed to his early unrecognized deafness. No lymph nodes were palpable. The tonsils were absent, having been surgically removed in early childhood (the tissue was not studied at that time and is not available). The spleen and liver were not enlarged.

Initial blood studies revealed a hemoglobin of $13.1 \mathrm{mg} / 100 \mathrm{ml}$ and a white blood count of $16,100 / \mathrm{mm}^{3}$ with $44 \%$ segmented polymorphonuclear cells, $21 \%$ bands, $23 \%$ lymphocytes, $9 \%$ monocytes, and $3 \%$ eosinophils. The chest $\mathrm{x}$-ray was normal without evidence of chronic disease. No thymic shadow could be seen. An extensive work-up of $\mathrm{T}$ and $\mathrm{B}$ cell function was undertaken as described under Methods. Results appear in Tables 1, 2, and 3. In general he was found to have low levels of $\operatorname{IgG}$ and absent $\operatorname{IgA}$. Low levels of IgM were present. A small percentage of B cells were detected by rosetting and by immunofluorescent techniques.

Because of his poor clinical response to exogenous IgG administration and the paradoxical presence of circulating $\mathrm{B}$ cells, we elected to begin a course of therapy with transfer factor. Three biweekly doses of transfer factor $\left(2 \times 10^{8}\right.$ lymphocytes/dose $)$ were administered, followed by trimonthly booster doses. Since the onset of transfer factor therapy, the patient has been maintained essentially free of infections and is without symptomatic complaints of any kind.

\section{METHODS}

\section{SKIN TESTS}

Cutaneous reactivity to a variety of skin test reagents were studied, including ( 1 ) Candida albicans extract (CAg, allergenic extract (29)) used in dilutions of $1: 1000$ and $1: 100$ in sterile saline; (2) streptokinase-streptodornase (Varidase (30)), used at doses of $10-2.5$ units and $40-10$ units diluted in sterile saline; and (3)
Trichophyton extract (Trich, allergenic extract (29)), used in dilutions of $1: 1000$ and $1: 100$ in sterile saline. These skin test reagents were injected intradermally in the volar aspect of the patient's forearm in volumes of $0.1 \mathrm{ml}$. The largest diameter of the indurated area was measured in millimeters with calipers at 24 and $48 \mathrm{hr}$. Any induration was considered a positive response. Erythema was not used as an indication of a positive reaction.

\section{T CELL ROSETTES}

T cell rosettes were assayed by the method of Wybran et al. (28). Lymphocytes, isolated on a Ficoll-Hypaque gradient (3), were placed in plastic tubes containing $0.05 \mathrm{ml}$ heat-inactivated fetal calf serum which had been absorbed previously with sheep red blood cells (RBC). $0.2 \mathrm{ml}$ of sheep RBC $\left(8 \times 10^{6}\right)$ were added with a final ratio of sheep $\mathrm{RBC}$ to lymphocytes of $8: 1$. The tubes were spun for $5 \mathrm{~min}$ at $800 \mathrm{rpm}$ and then were left undisturbed at room temperature for $60 \mathrm{~min}$. The cell pellets were then resuspended by gentle shaking and two lots of 500 lymphocytes were counted on a standard hemocytometer. A rosette-forming cell (RFC) was considered to be a lymphocyte with at least three adherent sheep $\mathrm{RBC}$. The results are expressed as the percentage of RFC per total number of lymphocytes present. Normal values for our lab are $45-55 \%$.

\section{IN VITRO PHYTOHEMAGGLUTIN (PHA) REACTIVITY}

Lymphocyte reactivity to PHA in vitro was studied according to the method of Waithe and Hirschhorn (27) using $4 \mu \mathrm{g} / \mathrm{ml}$ of MR68 PHA (31). DNA synthesis was measured at $72 \mathrm{hr}$ as the amount of incorporation of $\left[{ }^{14} \mathrm{C}\right]$ thymidine (32) (uniformly labeled with specific activity $53.8 \mathrm{mCi} / \mathrm{mmol}$ ) as determined with a Packard Tri-Carb liquid scintillation spectrophotometer model 3375.

\section{SERUM IMMUNOGLOBULINS AND ANTIBODY STUDIES}

Serum immunoglobulins were determined by the Mancini radial immunodiffusion method (20). In our laboratory the range of normal values for patients above 4 years of age is $\operatorname{lgG} 500-1,500 \mathrm{mg} /$ $100 \mathrm{ml}, \mathrm{IgA} 60-460 \mathrm{mg} / 100 \mathrm{ml}$, and $\mathrm{IgM} 30-130 \mathrm{mg} / 100 \mathrm{ml}$.

Isohemagglutinins were kindly assayed by the Mount Sinai Hospital Blood Bank.

Diphtheria antibody titers and tetanus antibody titers were performed at the Center for Disease Control, Atlanta, Ga., by the method of Schubert and Cornell (22). The results are expressed in hemagglutinating units (a.u.); 0.01 a.u. is considered a protective titer.

Neutralizing antibody to diptheria toxin was determined by injecting $0.1 \mathrm{ml}$ of active Schick toxin (33) intracutaneously in the volar aspect of the patinet's forearm (Schick test). The reaction was considered positive, indicative of the absence of neutralizing antibody of $\mathrm{IgG}$ class (4) if erythema was present at the site of injection after 5 days. To control for delayed hypersensitive reaction to the product, $0.1 \mathrm{ml}$ diphtheria toxoid (prepared by heating Schick toxin to $85^{\circ}$ for $30 \mathrm{~min}$ ) was injected into the volar aspect of the opposite forearm of the patient. Induration at $48 \mathrm{hr}$ at the control site distinguishes an immune response from a toxic, erythematous response to Schick toxin, which would appear in the nonimmune individual at 5 days on the opposite forearm.

\section{B CELL ROSETTES}

B cell rosettes were tested according to the method of Lay et al. (17). Sheep RBC $(0.25 \mathrm{ml})$ sensitized with rabbit anti-sheep amboceptor and complement (EAC) was mixed with $0.25 \mathrm{ml}$ containing $10^{6}$ lymphocytes. The cells were incubated at $37^{\circ}$ for 30 min with slow agitation provided by a rotary rack. Two hundred lymphocytes were then counted on a standard hemocytometer. An RFC was considered to be a lymphocyte with at least three adherent sheep RBC. The results are expressed as the percentage of RFC per total number of lymphocytes present. Normal values for our laboratory are $10-17 \%$. 


\section{IMMUNOFLUORESCENT STAINING}

Immunofluorescent staining was performed according to the method of Aiuti et al. (1). Fluorescein-conjugated antisera specific for the $\alpha$ heavy chain, for the $\gamma$ heavy chain, and for the $\mu$ heavy chain were obtained from Hyland Laboratories and used, each in a dilution of 1:8. Lymphocytes were isolated by an Isopaque-Ficoll gradient technique. Cells were washed three times in Hank's balanced salt solution and resuspended in a final concentration of 2 $\times 10^{6}$ cells $/ \mathrm{ml}$. Of this suspension, $0.1 \mathrm{ml}$ was mixed with $0.1 \mathrm{ml}$ fluorescein-conjugated $\mathrm{Ig}$ and incubated for $30 \mathrm{~min}$ at $4^{\circ}$. Cells were then washed three times with Hank's balanced salt solution and the percentage of fluorescent cells was evaluated with a Zeiss fluorescence microscope. For each heavy chain class 200 cells were counted.

\section{IN VITRO POKEWEEK MITOGEN REACTIVITY}

Lymphocyte reactivity to pokeweed mitogen was studied according to the method of Waithe and Hirschhorn (27) using a 1:100 dilution of pokeweed mitogen (34) diluted in RPMI 1640 (35) containing $100 \mu \mathrm{g} / \mathrm{ml}$ of streptomycin, $100 \mu / \mathrm{ml}$ penicillin, 29.2 $\mathrm{mg} / \mathrm{ml} \mathrm{L}$-glutamine, and $20 \%$ heat-inactivated fetal bovine serum. DNA synthesis was measured at $120 \mathrm{hr}$ as the amount of incorporation of $\left[{ }^{14} \mathrm{C}\right]$ thymidine (32) (uniformly labeled with specific activity $53.8 \mathrm{mCi} / \mathrm{mmol}$ ) using a Packard Tri-Carb liquid scintillation spectrophotometer model 3375 . Radioimmunoelectrophoresis was performed according to the method of Chessin et al. (6).

In Vitro Production of ${ }^{14} \mathrm{C}$-Labeled Proteins. Synthesis of immunoglobulins by stimulated peripheral blood lymphocytes was demonstrated with radioimmunoelectrophoretic techniques following the incorporation of ${ }^{14} \mathrm{C}$-amino acids into newly synthesized protein. A standard labeling medium was employed for this procedure consisting of Eagle's Spinner minimal essential medium-deficient in L-leucine and supplemented with L- $\left[{ }^{14} \mathrm{C}\right]$ leucine (specific activity $280 \mathrm{mCi} / \mathrm{mM}(32)$ ), $10 \%$ heat-inactivated fetal calf serum, and fresh L-glutamine. The final concentration for the radioactive amino acid was $1 \mu \mathrm{Ci} / \mathrm{ml}$. Lymphocytes stimulated by pokeweed mitogen as previously described were harvested at $72 \mathrm{hr}$ by centrifugation at $800 \mathrm{rpm}$ for $20 \mathrm{~min}$. For biosynthesis, $0.2-\mathrm{ml}$ aliquots of washed cells (approximately $1 \times 10^{7}$ ) were added to 1.8 $\mathrm{ml}$ labeling medium in screw disposable glass culture tubes, $16 \times$ $125 \mathrm{~mm}$. After incubation for $18 \mathrm{hr}$ at $37^{\circ}$ in an upright stationary position, the cultures were frozen, thawed, and centrifuged at $15,000 \times g$ for $20 \mathrm{~min}$. The supernatants were then dialyzed against 100 volumes of $0.014 \mathrm{M} \mathrm{NaCl}$ for $48 \mathrm{hr}$ at $4^{\circ}$ to remove unincorporated amino acid. The dialysate was lyophilized and reconstituted to $1 / 10$ the original volume with distilled water.

Radioimmunoelectrophoresis. Microimmunoelectrophoresis was performed in $1.5 \%$ agar with barbital acetate buffer, $\mu 0.05$, $\mathrm{pH} 8.6$ at $5 \mathrm{~V} / \mathrm{cm}$ for $60 \mathrm{~min}$. Precipitin arcs obtained by coprecipitation with human serum (12) were developed for $48 \mathrm{hr}$ with rabbit anti-human polyvalent and rabbit anti-human antisera specific for human immunoglobulin heavy chain, classes, $\alpha, \gamma$, and $\mu$. Radioautography was performed by exposing Kodak medical, no screen, $x$-ray film to the dried plates for 6 weeks. After the autoradiographs were developed the immunoelectrophoretic pattern was stained with fast green and the radioautographs were compared with the stained plates to determine electrophoretic mobilities of the labeled precipitin areas.

\section{TRANSFER FACTOR PREPARATION}

Transfer factor was prepared according to the method of Lawrence (15). Heparinized blood $(400 \mathrm{ml})$ was obtained from healthy donors who demonstrated a strongly positive cutaneous reactivity to 1:1000 CAg or Trichophyton. Lymphocytes, 3-4 $\times$ $10^{8}$, obtained from the leukocyte-rich plasma supernatant of the sedimented blood, were resuspended in $9 \mathrm{ml}$ sterile saline in Pyrex glass tubes. To this suspension of cells $1 \mathrm{mg}$ sterile DNase (36) was added with $0.5 \mathrm{ml}$ of $10 \%$ magnesium sulfate. The tubes were then serially quick frozen in acetone-Dry Ice followed by thawing in a $37^{\circ}$ water bath for a total of seven cycles. The extract was then dialyzed against $100 \mathrm{ml}$ sterile distilled water for $24 \mathrm{hr}$ at $4^{\circ}$. In these studies one unit of transfer factor is equivalent to $1 \times 10^{8}$ lymphocytes. Before use the lyophilized transfer factor was reconstituted in $2 \mathrm{ml}$ sterile distilled water, sterilized by $0.45-\mathrm{m} \mu$ Millipore filtration and then was immediately injected intramuscularly.

\section{RESULTS}

\section{T CELL RESPONSES (TABLE I)}

Our patient appeared to have grossly intact $\mathrm{T}$ cell responses. He was noted to have a mildly positive skin reactivity to Candida antigen and Trichophyton with induration at 1:100 dilution but not at 1:1000 dilution. No response to streptokinase-streptodornase was noted, although in our larger experience $75 \%$ of children 8 years of age tested respond to streptokinase-streptodornase. A normal percentage of circulating direct sheep $\mathrm{RBC}$ rosetting cells ( $\mathrm{T}$ cells) was detected $(60 \%)$. A control sample from a normal individual done at the same time showed $55 \% \mathrm{~T}$ cell rosettes.

The in vitro PHA response of our patient was comparable with that of the control with a rise from a baseline of $196 \mathrm{cpm}$ to 17,700 $\mathrm{cpm}$ by the patient's stimulated cells. This 90 -fold increment is similar to the 111-fold increment above background count demonstrated by the stimulated cells of the control.

\section{B CELL RESPONSES (TABLE 2)}

The patient was found to be blood group O. Isohemagglutinins against blood group substance A were 1:1. Diphtheria antitoxin antibodies were present in a protective titer of 0.038 a.u. No antibodies to Salmonella typhi groups $\mathrm{O}, \mathrm{H}, \mathrm{B}, \mathrm{C}_{1}, \mathrm{C}_{2}, \mathrm{D}$, and $\mathrm{E}$ were detected. Latex fixation for rheumatoid factor was negative. In spite of the presence of protective titers of diphtheria antibody in the serum, the patient's Schick test was positive. Circulating B cells as determined by EAC rosetting were present although in small numbers (4.6\% for the patient and $13 \%$ for the control). A small number of circulating cells could be shown by immunofluorescent techniques to bear surface immunoglobulins. Of these, $4 \%$ had $\alpha$ heavy chains, 3\% $\gamma$ chains and 3\% $\mu$ chains. Our patient responded to pokeweek mitogen with an increase from 29-760 $\mathrm{cpm}$. His 25 -fold increment in incorporation of $\left[{ }^{14} \mathrm{C}\right]$ thymidine with pokeweek mitogen stimulation is comparable with the 28 -fold increment demonstrated by the control.

By radioimmunoelectrophoresis it was shown that the patient's pokeweed mitogen-stimulated lymphocytes have the capacity to synthesize $\alpha, \gamma$, and $\mu$ chain classes of immunoglobulins (Fig. 1). The $\gamma$ heavy chains show wide heterogeneity. Only $\alpha$ and $\mu$ chains of restricted mobility were produced.

\section{RESPONSES TO TRANSFER FACTOR THERAPY (TABLE 3)}

Unfortunately, our transfer factor donor was not streptokinasestreptodornase positive. Since our patient had a positive skin response to both Candida antigen and Trichophyton before transfer factor therapy we were unable to test the effectiveness of our transfer factor by the acquisition by our patient of new skin test reactivities. Furthermore, no increase in the existing reactivities of our patient were noted after transfer factor. The patient remained positive to both Candida antigen and Trichophyton at 1:100 dilution, but did not respond to the 1:1000 dilution. Our donor was positive to 1:1000 dilutions of both skin test antigens. We ordinarily require the transfer of some cutaneous reactivity to control for the viability of the transfer factor used. That this transfer factor was active is demonstrated by its effect in an additional patient. A portion of this same transfer factor was found to increase the circulating $T$ cell rosettes of a patient with thymic dysplasia from $5 \%$ to $40 \%$ (5).

The patient's immunoglobulins were measured $14,50,70,168$, and 270 days after the discontinuation of exogenous IgG therapy (both pre- and post-transfer factor therapy). Before transfer factor 
Table 1. Pretransfer factor: $T$ cell responses ${ }^{1}$

\begin{tabular}{|c|c|c|c|}
\hline A. Skin tests: & Dilution & $\begin{array}{l}\text { Induration at } \\
48 \mathrm{hr}, \mathrm{mm}\end{array}$ & \\
\hline \multirow{2}{*}{ Candida antigen } & $1: 1000$ & 0 & \\
\hline & $1: 100$ & 6 & \\
\hline \multirow[t]{2}{*}{ Trichophyton } & $1: 1000$ & 0 & \\
\hline & $1: 100$ & 5 & \\
\hline \multirow[t]{2}{*}{ SK-SD, units } & $40-10$ & 0 & \\
\hline & $10-2.5$ & 0 & \\
\hline \multicolumn{4}{|l|}{$\begin{array}{l}\text { B. T cell rosettes } \\
\text { Patient } 60 \% \\
\text { Control 55\% }\end{array}$} \\
\hline C. PHA stimulation: & Baseline, ${ }^{2} \mathrm{cpm}$ & $\mathrm{PHA},{ }^{2} \mathrm{cpm}$ & Increment, -fold \\
\hline Patient & 196 & 17,700 & 90 \\
\hline Control & 211 & 23,400 & 111 \\
\hline
\end{tabular}

${ }^{1}$ SK-SD: streptokinase-streptodornase; PHA: phytohemagglutinin.

${ }^{2}$ Mean of triplicate cultures.

Table 2. Pretransfer factor: $B$ cell responses

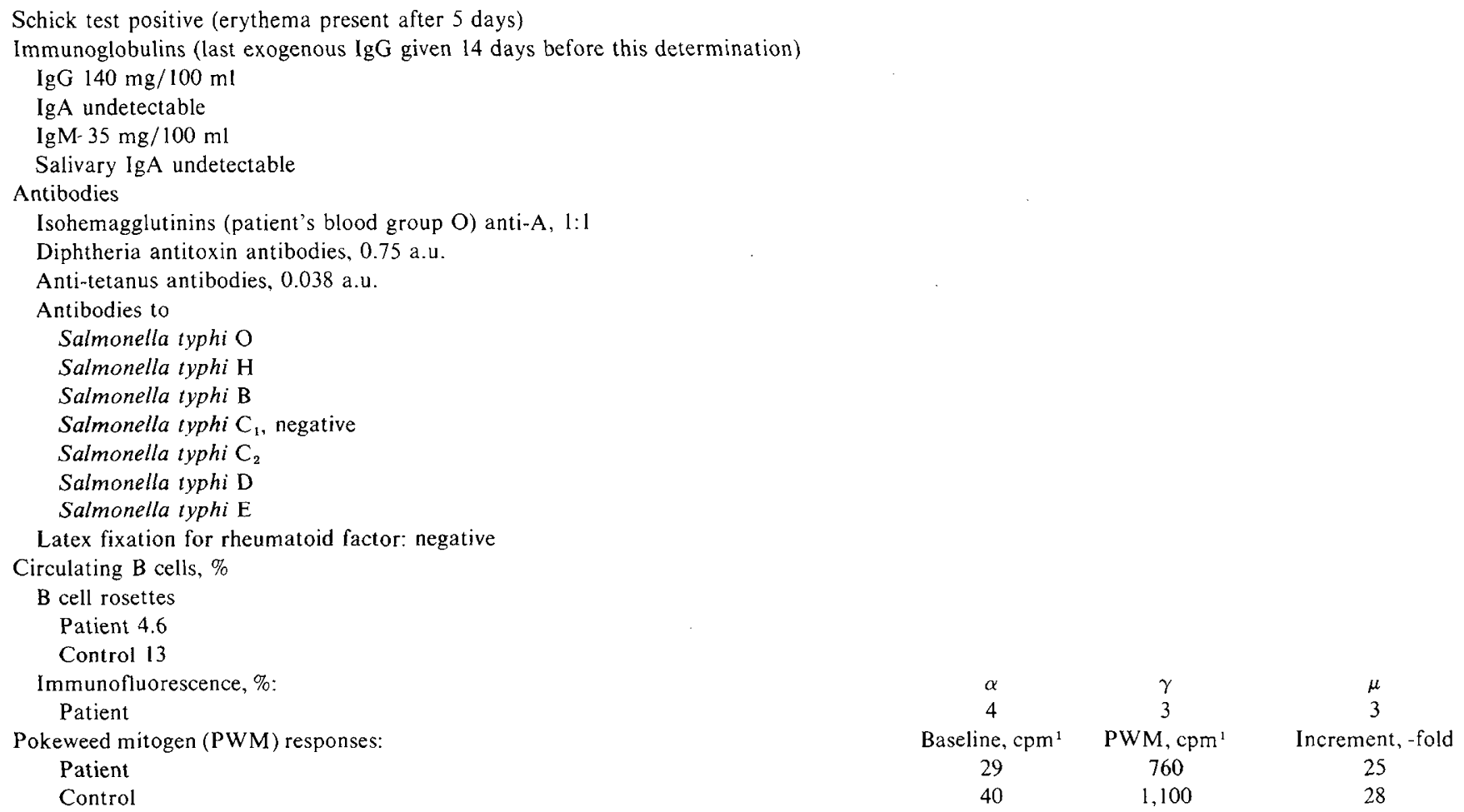

${ }^{1}$ Mean of triplicate cultures.

therapy ( 14 days after his last exogenous $\operatorname{IgG}$ ), the patient had an IgG of $140 \mathrm{mg} / 100 \mathrm{ml}$ and an IgM of $35 \mathrm{mg} / 100 \mathrm{ml}$. Fifty days after his last exogenous IgG (also pretransfer factor therapy) the patient's IgG was $70 \mathrm{mg} / 100 \mathrm{ml}$, and the $I g M$ was $10 \mathrm{mg} / 100 \mathrm{ml}$. After two doses of transfer factor ( 70 days after the last dose of exogenous $\mathrm{IgG}$ ) his serum $\mathrm{IgG}$ had decreased to $56 \mathrm{mg} / 100 \mathrm{ml}$ and his $\operatorname{IgM}$ had decreased to $7 \mathrm{mg} / 100 \mathrm{ml}$. After four doses of transfer factor, 168 days post-IgG therapy, his serum IgG rose to $110 \mathrm{mg} / 100 \mathrm{ml}$ and his $1 \mathrm{gM}$ decreased to undetectable levels. After 270 days his $\mathrm{IgG}$ was $130 \mathrm{mg} / 100 \mathrm{ml}$ with undetectable IgM. Throughout the course his salivary and serum IgA have remained undetectable. No change post-transfer factor therapy was noted in his Schick test which remained positive.

\section{DISCUSSION}

Although agammaglobulinemia has been considered a stem cell deficiency involving B lymphocytes, a number of investigators have questioned this hypothesis in recent years $(16,19,21)$. It has been shown that the peripheral blood lymphocytes of some patients with congenital aggamaglobulinemia have the capacity to synthesize normal amounts of $\gamma$-globulin when stimulated in short term culture $(8,25)$. Similarly, long term lymphoid cell lines, derived from patients with hypogammaglobulinemia have the capacity to synthesize immunoglobulins in vitro (25). These lines appear to be $\mathrm{B}$ cells as determined by EAC rosetting, immunofluorescence, and immunoglobulin synthesis (11).

As has been described for others (7), our patient with agammaglobulinemia and a history of recurrent infections was found to have small numbers of circulating B cells with surface immunoglobulins of the $\alpha, \gamma$, and $\mu$ heavy chain classes. It was further demonstrated by radioimmunoelectrophoresis that his lymphocytes, when stimulated in vitro with pokeweed mitogen, synthesized heavy chain classes of immunoglobulins with a restricted population of $\mu$ heavy chains. Low levels of serum $\operatorname{IgM}$ were present in this patient throughout his course, despite the extremely 

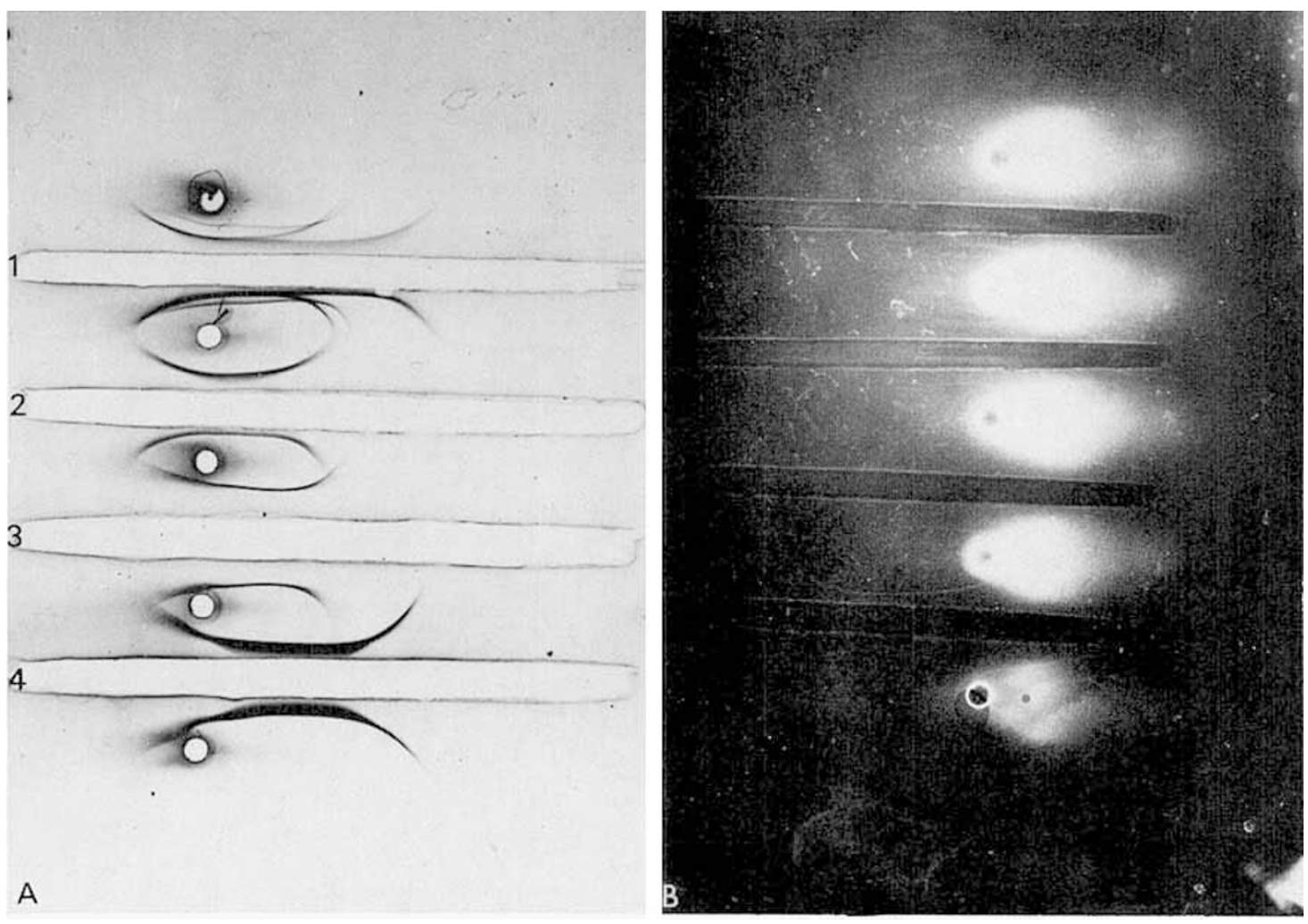

Fig. 1. Radioimmunoelectrophoretic study of the in vitro synthesis of immunoglobulins by the pokeweed mitogen-stimulated peripheral lymphocytes of patient JF. A: fast green-stained immunoelectrophoretic patterns for comparative study. B: autoradiograph of the coprecipitated, labeled heavy chains synthesized in vitro. Wells $(p)$ contain cell lysates from the patient. Trough $l$ was filled with rabbit anti-human polyvalent antiserum against human $\alpha, \gamma$, and $\mu$ heavy chain classes of immunoglobulin. Trough 2 was filled with rabbit anti-human antiserum specific for the $\alpha$ chain of human immunoglobulin. Trough 3 was filled with rabbit anti-human antiserum specific for the $\mu$ chain of human immunoglobulin. Trough 4 was filled with rabbit antihuman antiserum specific for the $\gamma$ chain of human immunoglobulin. Newly synthesized molecules of $\gamma$ chain with a broad range of mobility can be seen. $\alpha$ and $\mu$ chains with restricted mobility are also present.

Table 3. Significant changes posttransfer factor

\begin{tabular}{|c|c|c|c|c|c|c|}
\hline & $\begin{array}{l}\text { Postexogenous } \\
\operatorname{lgG} \text {, days }\end{array}$ & $\begin{array}{c}\operatorname{IgG} \\
\mathrm{mg} / 100 \mathrm{ml}\end{array}$ & $\mathrm{IgA}, \mathrm{mg} / 100 \mathrm{ml}$ & $\begin{array}{c}\text { Salivary } \\
\mathrm{IgA}, \mathrm{mg} / 100 \mathrm{ml}\end{array}$ & $\operatorname{IgM}, \mathrm{mg} / 100 \mathrm{ml}$ & Schick test \\
\hline Pretransfer factor & 14 & 140 & Undetectable & Undetectable & 35 & Positive \\
\hline Transfer factor, 2 doses & 70 & 56 & Undetectable & Undetectable & 7 & \\
\hline \multirow[t]{2}{*}{ Transfer factor, 4 doses } & 168 & 110 & Undetectable & Undetectable & Undetectable & Positive \\
\hline & 270 & 130 & Undetectable & Undetectable & Undetectable & \\
\hline
\end{tabular}

small amounts of this immunoglobulin in commercially prepared $\gamma$-globulin. It is presumed that this was endogenously synthesized in vivo, perhaps in response to the repeated administration of foreign $\gamma$-globulin. The presence of hemagglutinating antibody against diphtheria toxin in the face of a repeatedly positive Schick test further suggests that this IgM has antibody activity as has been previously described for patients with mucocutaneous candidiasis (4).

Patients with congenital agammaglobulinemia are presumed to have intact $\mathrm{T}$ cell function. Recently, however, Schiff et al. (21) have demonstrated that the lymphocytes of patients with infantile $x$-linked agammaglobulinemia have a diminished response to PHA. They postulate that these patients might be deficient in a restricted population of $T$ cells which may be necessary for the full maturation of $\mathrm{B}$ cell function. In a rapidly expanding series of elegant experiments in many laboratories (13), it has been shown for the mouse that $T$ cells are necessary for appropriate immunoglobulin production and antibody synthesis by $B$ cells. $T$ cell interaction appears to be instrumental in the switch from IgM to IgG synthesis. Subpopulations of $T$ cells may lead to $B$ cell supression as well as facilitation (10).
By gross testing, the $\mathrm{T}$ cell responses of our patient appeared to be intact with normal numbers of circulating $T$ cells, cutaneous reactivity to a variety of antigens, and in vitro $\mathrm{PHA}$ responsiveness. The presence of circulating IgM, however, suggested that the patient's B cells can function but that faulty T-B cell interactions might exist.

Since 1954, Lawrence has reported the transfer of cell-mediated immunity in man with an extract of peripheral leukocytes from immune individuals. The activity, presumably derived from $T$ lymphocytes, is associated with a low molecular weight material, $<10,000$ (current estimates 4,000-6,000), which can be separated from immunoglobulins and large molecular weight informational proteins by dialysis. Because it is free of HL-A antigens and appears to have little or no immunogenicity, dialyzable transfer factor is now under intensive study as a therapeutic agent in a variety of immune and neoplastic disorders $(23,26)$. Transfer factor has been used in the therapy of the Wiskott-Aldrich syndrome, chronic mucocutaneous candidiasis, Swiss-type agammaglobulinemia, malignancies, lepromatous leprosy, and disseminated vaccinia with varying degrees of success. Although it seems to be most useful in T cell disorders, transfer factor similarly 
has been shown to transfer enduring delayed sensitivity to a variety of antigens in patients with congenital agammaglobulinemia (2). No apparent alteration in B cell functions, however, has been noted in these patients after therapy with transfer factor. The direct influence of transfer factor on T-B cell interaction has not been reported.

It was clear that administration of exogenous $\gamma$-globulin by intramuscular injection as frequently as every 2 weeks did not significantly increase the serum IgG levels in our patient nor did it decrease his pyogenic infections. It is possible that he had an unusual catabolism of these proteins (not investigated) and/or that the exogenous $\gamma$-globulin he was given suppressed his endogenous synthesis by potentially functional B cells. Within 50 days of the discontinuation of $\gamma$-globulin therapy, his serum IgG fell to 70 $\mathrm{mg} / 100 \mathrm{ml}$. Although it is possible that he may have subsequently begun to produce endogenous $\mathrm{IgG}$, we attempted to augment his responses at the time with transfer factor. After treating the patient with three doses of transfer factor at biweekly intervals, followed by a fourth dose 1 month later, his IgM level became undetectable with an increase in his $\mathrm{IgG}$ level from a low of 50 $\mathrm{mg} / 100 \mathrm{ml}$ to $130 \mathrm{mg} / 100 \mathrm{ml}$. This is comparable with the levels achieved with exogenous IgG therapy. This level has remained stable for the past 12 months with trimonthly transfer factor injections. Of particular interest, despite no appreciable difference in IgG level and the apparent loss of circulating $\operatorname{IgM}$, this regimen, which has included stopping exogenous $\gamma$-globulin and the administration of transfer factor, has been accompanied by an overall improvement in the patient's clinical state. Whereas before transfer factor with biweekly $\gamma$-globulin doses he had at least 1 infection/month with hospitalizations every 2-3 months, with the new therapeutic regimen he has been virtually free of infections for the past 12 months. One presumed viral illness occurred during the 7 th month of transfer factor therapy. The patient had an uneventful course and recovered without sequelae. This prolonged amelioration in the clinical state in our experience is unlikely to reflect the natural variability of his immunodeficiency disorder.

Lim et al. (18) have suggested that transfer factor may nonspecifically augment the immune responses of the recipient. Our studies in this patient with agammaglobulinemia have shown that transfer factor therapy may affect immunoglobulin synthesis as has been suggested by Gelfand et al. (9), but we are hard put to provide specific immunologic proof of this interaction. We have noted the disappearance of the serum $\operatorname{IgM}$ of our patient during transfer factor therapy with resulting increases in his serum IgG levels. Although it is possible that his alteration in serum immunoglobulins results from removal of the suppression by exogenous $\gamma$-globulin of his endogenous synthesis, we suspect that the switch from IgM to IgG synthesis may have been accomplished by a nonspecific facilitation by transfer factor of T-B cell interaction in our patient. Unfortunately, no specific changes in antibody response (particularly Schick reactivity) were detected to confirm that a switch in antibody production had occurred as well. Since the radioimmunoelectrophoretic patterns of heavy chains newly synthesized by his stimulated lymphocytes demonstrated wide heterogeneity, it is unlikely that this additional approach will offer any immunologic confirmation of the production of new species of $\operatorname{IgG}$ in our patient. We await further detailed reports of the effects of transfer factor in the therapy of patients with $B$ cell dysfunction.

\section{SUMMARY}

Transfer factor therapy has been shown to alter the clinical course of a patient with agammaglobulinemia. Because of the concurrent discontinuation of exogenous $\gamma$-globulin administration, it is difficult to attribute changes to a particular aspect of therapy. Further reports of the effects of transfer factor in the therapy of patients with $\mathrm{B}$ cell disorders are needed.

\section{REFERENCES AND NOTES}

1. Aiuti, F., Fontana, L., and Gatti, R. A.: Membrane-bound immunoglobulin (Ig) and in vitro production of $\mathrm{Ig}$ by lymphoid cells from patients with primary immunodeficiencies. Scand. J. Immunol., 2: 9 (1973).

2. Amman, A. J., Wara, D., and Salmon, S.: Transfer factor: Therapy in patients with deficient cell-mediated immunity and deficient antibody-mediated immunity. Cell. Immunol., 12: 94 (1974).

3. Boyum, A.: Separation of leucocytes from blood and bone marrow. Scand. J. Clin. Lab. Invest., 21 (suppl.): 97 (1968).

4. Cahill, L. T., Ainbender, E., and Glade, P. R.: Chronic mucocutaneous candidiasis: $T$ cell deficiency associated with $B$ cell dysfunction in man. Cell. Immunol., in press.

5. Cahill, L. T., Kaffe, S., Papageorgiou, P. S., Petigrow, C. S., and Glade, P. R.: Partial reconstitution of a patient with congenital thymic dysplasia by fetal tissue and transfer factor. (Society for Pediatric Research, 44th Annual Meeting, Washington, D.C., 1974).

6. Chessin, L. N., Glade, P. R., Asofsky, R., Baker, P. D., Reisfeld, R., and Terry, W.: Studies on human peripheral blood lymphocytes in vitro. J. Immunol., 101: 458 (1968).

7. Cooper, M. D., and Lawton, A. R.: Circulating B-cells in patients with immunodeficiency. Amer. J. Pathol., 69: 513 (1972).

8. Cooperband, S. R., Rosen, F. S., and Kibrick, S.: Studies on the in vitro behavior of agammaglobulinemic lymphocytes. J. Clin. Invest., 47: 836 (1968).

9. Gelfand, E. W., Baumal, R., and Huber, J.: Polyclonal gammopathy and lymphoproliferation after transfer factor in severe combined immunodeficiency disease. N. Engl. J. Med., 289: 1385 (1975).

10. Gershon, R. K., and Paul, W. E.: Effect of thymus-derived lymphocytes on amount and affinity of anti-hapten antibody. J. Immunol., 106: 872 (1971).

11. Glade, P. R., and Beratis, N. G.: Progr. Med. Genet., 11: 000 (1974).

12. Hochwald, G. M., Thorbecke, G. J., and Asofsky, R.: A new technique for the demonstration of the synthesis of individual serum proteins by tissues in vitro. J. Exp. Med., 114: 459 (1961).

13. Katz, D. H., and Benacerraf, B.: The regulatory influence of activated $T$ cells on B cell responses to antigen. Advan. Immunol., 15: 1 (1972)

14. Lawrence, H. S.: Transfer factor. Advan. Immunol., 2: 195 (1969).

15. Lawrence, H. S., and Al-Askari, S.: The preparation and purification of transfer factor. In: B. R. Bloom and P. R. Glade: In Vitro Methods in Cell Mediated Immunity, p. 531 (Academic Press, New York, 1971).

16. Lawton, A. R., Royal, S. A., Self, K. S., and Cooper, M. D.: IgA determinants on B-lymphocytes in patients with deficiency of circulating IgA. J. Lab. Clin. Med., 80: 26 (1972).

17. Lay, W. H., and Nussenzweig, V.: Receptors for complement on leucocytes. J. Exp. Med., 128: 991 (1968).

18. Lim, S. D., Fusaro, R., and Good R. A.: The treatment of leprosy patients with intravenous infusions of leukocytes from normal persons. Clin. Immunol. Immunopathol., I: 122 (1972).

19. Luckasen, J. R., Sabad, A., Gajl-Peczalska, K. J., and Kersey, J. H.: Lymphocytes bearing complement receptors, surface immunoglobulins and sheep erythrocyte receptors in primary immunodeficiency diseases. Clin. Exp. Immunol., 16: 535 (1974).

20. Mancini, G., Carbonara, A. O., and Heremans, J. F.: Immuno-chemical quantitation of antigens by single radial immunodiffusion. Immunochemistry, 2: 235 (1965).

21. Schiff, R. I., Buckley, R. H., Gilbertsen, R. B., and Metzgar, R. S.: Membrane receptors and in vitro responsiveness of lymphocytes in human immunodeficiency. J. Immunol., 112: 376 (1974).

22. Schubert, J. H., and Comell, R. G.: Determination of diphtheria and tetanus antitoxin by the hemagglutination test in comparison with tests in vivo. J. Lab. Clin. Med., 52: 737 (1958).

23. Spitler, L. E., Levin, A. S., and Fudenberg, H. H.: Human lymphocyte transfer factor. Methods Cancer Res., 8: 59 (1972).

24. Spitler, L. E., Levin, A. S., Stites, D. P., Fudenberg, H. H., Priofsky, B., August, C. S., Stiehm, E. R., Hitzig. W. H., and Gatti, R. A.: The Wiskott-Aldrich syndrome, results of transfer factor therapy. J. Clin. Invest., 51: 3216 (1972).

25. Stites, D. P., Levin, A. S., Austin, K. E., and Fudenberg, H. H.: Immunoglobulin biosynthesis in cultures from hypogammaglobulinemias and paraproteinemias. J. Immunol., 107: 1376 (1971).

26. Uhr, J. W., and Landy, M. (eds): Proceedings of an International Conference (Academic Press, New York, 1971).

27. Waithe, W. I., and Hirschhorn, K.: An assay of lymphocyte blastogenesis based on measurement of the rate of protein synthesis. In: B. R. Bloom and P. R. Glade: In Vitro Methods in Cell Mediated Immunity, p. 455 (Academic Press, New York, 1971)

28. Wybran, J., Carr, M. C., and Fudenberg, H. H.: The human rosette-forming cell as a marker of a population of thymus-derived cells. J. Clin. Invest., 51: 2537 (1972).

29. Hollister-Stier Labs., Yeadon, Pa.

30. Lederle Labs., Pearl River, N. Y.

31. Wellcome Research Labs., Research Triangle Park, N. C.

32. New England Nuclear Corp., Boston, Mass.

33. Wyeth Labs., Marietta, Pa.

34. Grand Island Biological Co., Berkeley, Calif.

35. Associated Biomedic Systems, Inc., Buffalo, N. Y.

36. Worthington Biochemical Corp., Freehold, N. J.

37. Dr. P. R. Glade is a recipient of a Research Career Development Award AI46371 of the United States Public Health Service. The current mailing address for Dr. P. R. Glade is: University of Miami School of Medicine, Department of Pediatrics, Division of Infectious Diseases and Immunology, 
P. O. Box 520875, Biscayne Annex, Miami, Fla. 33152 (USA).

38. This work was supported by Research Grant AIl0422 and Training Grant Al00445 from the National Institute of Allergy and Infectious Diseases, and Genetic Center Grant GM19443 from the National Institute of General Medical Sciences, National Institutes of Health, United States Public Health
Service and a grant from the Goldhirsch Foundation, New York, N. Y. 39. Requests for reprints should be addressed to: N. M. Zaldivar, M.D. Department of Pediatrics, Division of Infectious Diseases and Immunology, P.O. Box 520875, Biscayne Annex, Miami, Fla. 33152 (USA).

40. Accepted for publication March 10, 1975.

\title{
The Effect of Increased Pulmonary Blood Flow on the Pulmonary Vascular Bed in Pigs
}

\author{
BEAT FRIEDLI, ${ }^{17)}$ GERALDINE KENT, AND B. S. LANGFORD KIDD \\ WITH THE TECHNICAL ASSISTANCE OF M. LUIDE AND F. HAMILTON \\ Department of Cardiology and Research Institute, The Hospital for Sick Children, Toronto, Ontario, Canada
}

Extract

Increased pulmonary blood flow was produced in 1-month-old piglets by means of left pneumonectomy, arteriovenous fistulas in the neck, and a combination of both. Physiologic and histologic studies of the pulmonary vascular bed were done 1-9 months after operation.

A progressive, moderate increase in pulmonary artery (PA) pressure was observed, especially between 1 and 6 months after surgery. This was flow related, i.e., the group with the highest flow (pneumonectomy plus fistula) was found to have the most prominent increase in pressure. Mean PA pressure at 6 months was $28.7 \pm$ $0.07 \mathrm{~mm} \mathrm{Hg}$ in this group, vs $24.4 \pm 0.48 \mathrm{~mm} \mathrm{Hg}$ in the group with pneumonectomy alone and $17.2 \pm 0.48 \mathrm{~mm} \mathrm{Hg}$ in controls $(P<$ 0.01 ). The pressure response to hypoxia in pigs with high pulmonary blood flow was not different from that found in control animals.

Histologic studies revealed that small arteries and arterioles of pigs with high pulmonary blood flow had a decreased relative wall thickness because of dilation up to 6 months follow-up. This was flow related, the group with the highest flow having the lowest wall thickness to vessel diameter ratio; relative wall thickness (in percentage of the vessel diameter) at 6 months was $6.1 \pm 0.44 \%$ in pigs with pneumonectomy plus fistula, vs $\mathbf{9 . 6} \pm \mathbf{0 . 4 0} \%$ in the group with pneumonectomy alone and $11.2 \pm 0.61 \%$ in controls $(P<$ $0.01)$. In the group with the highest flow, thick walled arterioles appeared at 9 months follow-up, scattered among dilated ones; mean medial wall thickness in these animals increased significantly between 6 and 9 months after operation, ranging from $6.1 \pm 0.44 \%$ to $11.3 \pm 0.73 \%(P<\mathbf{0 . 0 1})$.

In five animals with high flow, the right $\mathrm{PA}$ ( main branch) showed patchy intimal thickening, small cystic spaces filled with mucopolysaccharides in the media, and muscular hypertrophy.

\section{Speculation}

Some changes usually seen in pulmonary hypertension were produced in this model by high pulmonary blood flow in the presence of only mild to moderate elevation of PA pressure. The dilation observed in the pulmonary arteries and arterioles may have been a pathogenetic factor; indeed, it is likely that wall tension rather than intravascular pressure induces vascular changes; wall tension (according to Laplace's law) depends on vessel diameter as well as intravascular pressure. Therefore, in a dilated vascular bed, wall tension will increase considerably with only moderate increase in PA pressure, inducing changes usually seen with more severe degrees of pulmonary hypertension.

Pulmonary vascular disease remains a serious complication of congenital heart disease with a left-to-right shunt. Little is known about the pathogenesis of this condition, but three factors are believed to be involved: increased pulmonary blood flow, a raised pulmonary artery pressure, and high left atrial pressure.

Experimental models used to study pulmonary vascular disease often involve anastomoses between aorta and pulmonary artery, whereby two if not all three of the above mentioned factors are produced $(1,4)$.

In an attempt to identify changes induced by high flow alone, we have created "obligatory" shunts in piglets $1-2$ months old; this was obtained by unilateral pneumonectorny, creation of systemic arteriovenous fistulae, and a combination thereof.

\section{METHODS}

Three litters of piglets were used. Each litter was divided into four groups: two pigs were not subjected to surgery (controls); two underwent left pneumonectomy at 4 weeks of age with no other operation; two had pneumonectomy at the same age, followed by creation of arteriovenous (A-V) fistulas at 4-6 weeks of age; two had A-V fistulas alone. Thus, there were eight animals in each group. A-V fistulas were created between the carotid artery and the internal jugular vein. Incisions $2 \mathrm{~cm}$ long were made in these vessels and a side-to-side anastomosis created by continuous sutures. A unilateral fistula was made in pigs of the first litter, and bilateral anastomoses in those of the second and third litters. One litter was followed up for 1-3 months, the second for 6 months, and the third for 9 months. Subsequently, the pigs were killed for histologic study.

Hemodynamic studies were repeated at 1, 3, 6, and 9 months for as long as the animals were alive. 